\title{
An Estimation of the Coastal Premium for Residential Housing Prices in San Diego County
}

\author{
Stephen J. Conroy • Jennifer L. Milosch
}

Published online: 22 July 2009

(C) The Author(s) 2009. This article is published with open access at Springerlink.com

\begin{abstract}
The authors attempt to estimate the "coastal premium" - additional value conferred on a residence from being located near the coast - of single family homes in San Diego County, while controlling for other locational and structural characteristics. A previous investigation published in 2001 for south Orange County found that moving away from the coast by one mile was associated with a $\$ 42,000$ lower housing price. Intrigued by this finding, we investigate whether (a) a similar coastal premium exists for all of San Diego County and (b) the premium varies by incremental distance from the coast (e.g., for 500-feet increments). Using data from 9,755 San Diego County home sales in 2006, results presented here suggest that for a median-priced home $(\$ 540,000)$ at the mean distance from the coast (approximately 9 miles - and considerably farther than the Orange County estimate) a onemile increase in distance from the coast would reduce the sale price by approximately $\$ 8,680$. Specifying by specific distance increments, we find that the coastal premium is approximately $101.9 \%$ for houses within 500 feet of the coast (i.e., their value is $101.9 \%$ higher than similar homes located beyond six miles of the coast), falling to $62.8 \%$ for homes between 500 and 1,000 feet, declining to approximately $3.3 \%$ for homes located between five and six miles of the coast, disappearing entirely beyond around six miles. Since average comparisons of the sort initially considered in this analysis can be very misleading, researchers should consider the nonlinear incremental distance effects in model specifications.
\end{abstract}

Keywords Coastal premium $\cdot$ Hedonic model $\cdot$ San Diego $\cdot$ Housing prices · California housing

S. J. Conroy $(\bowtie)$

Department of Economics, School of Business Administration, University of San Diego, San Diego, CA 92110-2492, USA

e-mail: sconroy@sandiego.edu

J. L. Milosch

Department of Economics, University of California, 2127 North Hall, Santa Barbara,

CA 93106-9210, USA

e-mail: jmilosch@gmail.com 
JEL Classification $\mathrm{R} 21 \cdot \mathrm{Q} 31$

\section{Introduction}

There are many reasons why households may choose to locate near the coast. For example, households may perceive the coast as a natural recreational resource which confers utility (recreational value) through a myriad of uses such as swimming, wading, surfing, sunbathing, etc. The closer households locate to this recreational resource, the lower the travel costs associated with its use (Major and Lusht 2004). The coast also confers non-recreational benefits. Given the prevailing westerly breezes and relatively cool Pacific Ocean temperatures, locating near the coast in San Diego County, California - as in other areas along the West Coast - is associated with generally cleaner air and cooler ambient temperatures in the summer months and slightly warmer nights in the winter months. For those who locate within viewing distance of the water, coastal views may also provide another amenity (Rodriguez and Sirmans 1994; Benson et al. 1998).

At the same time, locating near the coast in San Diego County has some drawbacks. The primary disadvantage is the increased number of cloudy days, especially pronounced in the late spring. "May gray" and "June gloom" are common descriptors for these marine layer effects (which may burn off for a time in the afternoon) that predominate during the late spring and early summer months and are especially pronounced near the coast. Other potential drawbacks include higher population densities and historically higher traffic congestion (with limited land alternatives) along coastal routes, especially Interstate 5, increasing commuting times to the central business district of San Diego.

In this current endeavor, we wish to estimate whether there is additional value conferred on a residence from being located near the coast - a "coastal premium"in San Diego County. Our a priori belief is that the benefits discussed above exceed the costs and that a coastal premium does exist, even when controlling for other important structural and spatial attributes.

As with other natural resources such as urban wetlands (Mahan et al. 2000), lakes (Kilpatrick et al. 2007), ponds (Plattner and Campbell 1978) forest (Tyravainen and Miettinen 2000), and open space (Irwin 2002) we expect that proximity to the Pacific coastline will confer positive market advantages to sellers. In the recreational rental market on the Outer Banks of North Carolina, Taylor and Smith (2000) found that environmental amenities, including access to the ocean conferred product-differentiating market power. Similarly, Rinehart and Pompe (1994) found that wider beaches were associated with higher housing sales prices for South Carolina resort areas. In both of these studies, as well as one by Major and Lusht (2004) on mostly high-priced rental housing in New Jersey, closer proximity to the ocean was associated with higher housing prices. However, these papers analyzed resort and rental properties, which may be a different market than the single family dwelling market. On the West Coast, an investigation of the impact of new highways on housing prices in Orange County, California by Boarnet and Chalermpong (2001) included distance from the ocean as a control. 
The authors found each mile away from the coast to be associated with a $\$ 42,000$ reduction in selling price.

In this current analysis, we hope to improve upon previous investigations in three ways. First, we wish to expand the relative paucity of studies conducted on the West Coast, where ocean temperatures are generally colder and the hurricane risk much lower than on the Eastern Seaboard or Gulf Coast. Second, we wish to include all single family homes sold in a large Metropolitan Statistical Area (MSA), not just rental housing or those found primarily in resort areas. Third, by emphasizing distance from the coast, we can employ various model specifications which convey additional information than simply using distance as a control variable.

\section{Hedonic Models}

The hedonic pricing model for housing is discussed extensively elsewhere (see Freeman 2003 for a summary) and is based largely on seminal work in this area by Ridker (1967), Ridker and Henning (1967) and Rosen (1974). For the purposes of this investigation, we will present an abbreviated discussion which emphasizes the approach taken here.

Since the hedonic pricing function represents actual sales data, we assume that the price represents an equilibrium of demand for and supply of single family dwellings in the region. In reality, the assumption of equilibrium would depend on the actual market robustness. The hedonic estimation derives from the fact that housing is a composite good; i.e., it contains a bundle of attributes. We will group these attributes into three categories: structural characteristics, spatial and neighborhood characteristics, and the variable of interest, distance from the coast. The standard hedonic price function could be represented as:

$$
P=f(\mathbf{S}, \mathbf{T}, \mathbf{C})
$$

where $P$ is the sale price of housing, $S$ is a vector of structural characteristics such as the number of bedrooms, bathrooms, square footage, etc., $\boldsymbol{T}$ is a vector of spatial and neighborhood characteristics such as school quality, distance from major roads and distance from the central business district, and $C$ is the variable of interest, distance from the coast.

\section{Data}

The housing sales data were obtained from DataQuick ${ }^{\circledR}$ and provided by the Burnham-Moores Center for Real Estate at the University of San Diego. The data set contained initially 16,471 observations of single family homes that were sold in San Diego County during 2006. The data provided information on the sales price of the house, parcel number, census tract, number of bedrooms and 
bathrooms, year the house was built, size of the lot, size of the structure, and address of the house.

There were a number of observations with missing information in one or more of these categories. We deleted approximately 6,000 observations with missing data for the square footage of the lot, since prior investigations have found this to be an important housing attribute. We then removed observations containing outliers or seemingly impossible information implying errors in data entry or non-market transactions (e.g., sales prices under $\$ 100,000$, a 1,800 square feet house with 17.5 bathrooms, etc.). The final data set contained 9,755 observations. For other apparently random omissions for specific attributes, we applied the "hot-deck" imputation method used by the U.S. Census Bureau (Zajac 2003; Obenski et al. 2006), in which the missing information was replaced by data from the closest reported parcel (numerically) in the same census tract.

Based on results from prior investigations (e.g., Sirmans et al. 2006) and data availability, we included the following variables as "structural" controls: square feet of the lot, square feet of the structure, number of bedrooms and bathrooms, and age of the house in 2006 (created from subtracting the year built from 2006.) To develop the "spatial" or distance variables, we overlaid the sales data with spatial data from SanGIS, using a raster map created in ArcGIS 9.0 that estimated the closest Euclidian linear distance (in feet) from the centroid of each individual housing parcel to the edge of the location of interest (see Fig. 1). Using this software, we created variables for distance from each parcel to: the Pacific coast, the central business district (4th Street and Broadway in downtown San Diego), and the nearest major highway (I-5, I-8, I-805, or I-15) (see Boarnet and Chalermpong 2001). ${ }^{1}$ Based on the Tiebout (1956) residential sorting hypothesis, we expect public school quality to matter. Prior research by Brasington (1999) suggests that proficiency test pass rates are an effective measurement of public school quality so we included the base academic performance indicator (API) score for each elementary school district in 2006 (by searching on the California Department of Education's website at http:/www.cde.ca.gov/TA/ac/ap/apireports. asp). [The base API score is on a scale of 200 to 1,000 and calculated based on student performance on a number of standardized tests (http://www.cde.ca.gov/TA/ ac/ap/glossary07b.asp\#ga3).]

\section{Procedures}

There is no theoretical motivation for any particular functional form as other research on housing prices has employed different functional forms. Thus, econometric estimation of the hedonic price function can take on a variety of forms,

\footnotetext{
"We do not attempt to control for "view" in this current endeavor because the terrain in San Diego County is quite heterogeneous - with many properties having views of the ocean, estuaries, bays, rivers, mountains and canyons - and many that have more than one of these. While some Multiple Listing Service (MLS) data contain information about "views" these data are notoriously unreliable.
} 


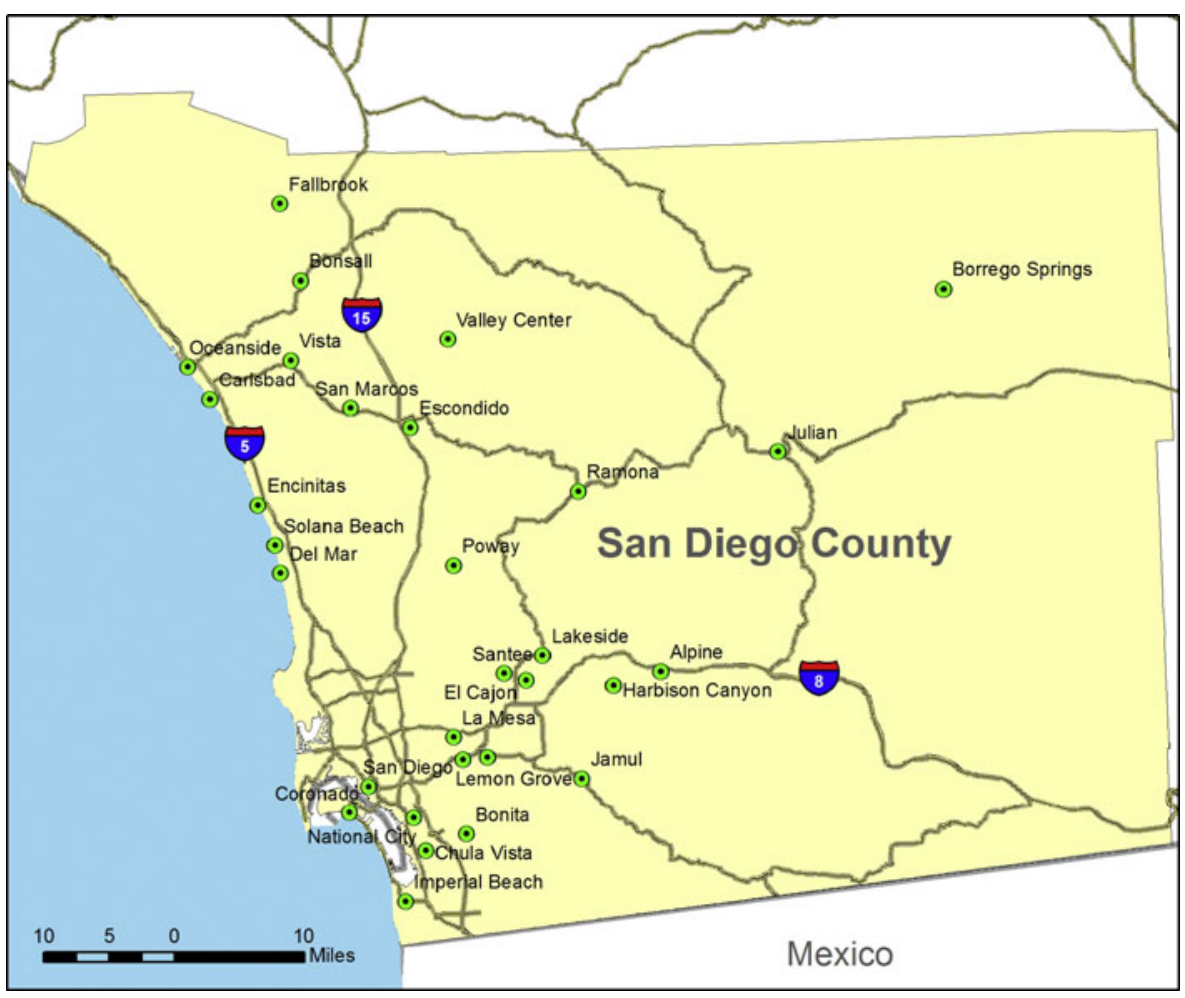

Fig. 1 Map of San Diego county

including the standard hedonic price function, semi-log, log-log and Box-Cox. We use the semi-log functional form here. ${ }^{2}$ The model is as follows:

$$
\ln P_{i}=\alpha_{i}+\sum_{j=1}^{J} \beta_{j} S_{i j}+\sum_{k=1}^{K} \beta_{k} T_{i k}+\beta_{l} C_{i}+\sum_{m=1}^{M} \beta_{m} F_{i m}+v_{i},(\text { fori }=1,2, \ldots n)
$$

where $\ln P_{i}$ is the natural $\log$ of price for observation $i, S_{i j}$ is the $j$ th structural variable for observation $i, T_{i k}$ is the $k$ th spatial and neighborhood variable for observation $i, C_{i}$ is the distance-to-coast variable, $F_{i m}$ is the $m$ th fixed effects variable for observation $i, \alpha_{i}$ is the intercept term for observation $i$, the $\beta$ 's are the estimated coefficients, and $\nu_{i}$ is the error term for observation $i$. A plot of price on distance from coast suggests that the effect may decline with distance (see Fig. 2), so we actually include the natural log of distance from the coast in Model 1.

\footnotetext{
${ }^{2}$ Box-Cox transformations have been demonstrated elsewhere (Cropper et al. 1988; Blackley et al. 1984) to be a preferred method to reduce coefficient bias. Thus, we estimated Eq. (2) using a Box-Cox transformation and, while the theta and lambda coefficients $(-0.14$ and 0.17 , respectively) were significant, the magnitudes were close to zero, suggesting that a log transformation is appropriate. This coincided with our empirical results presented here favoring the semi-log specification. A further consideration against using Box-Cox is that it does not allow for specification of dummy variables (such as those specified for the variables-of-interest in Eq. (3)). Since the housing price data have a long righthand side tail, a logarithmic adjustment is likely to improve upon linear models. See Mahan et al. (2000); and Irwin 2002, for similar methodological approaches to this estimation question.
} 


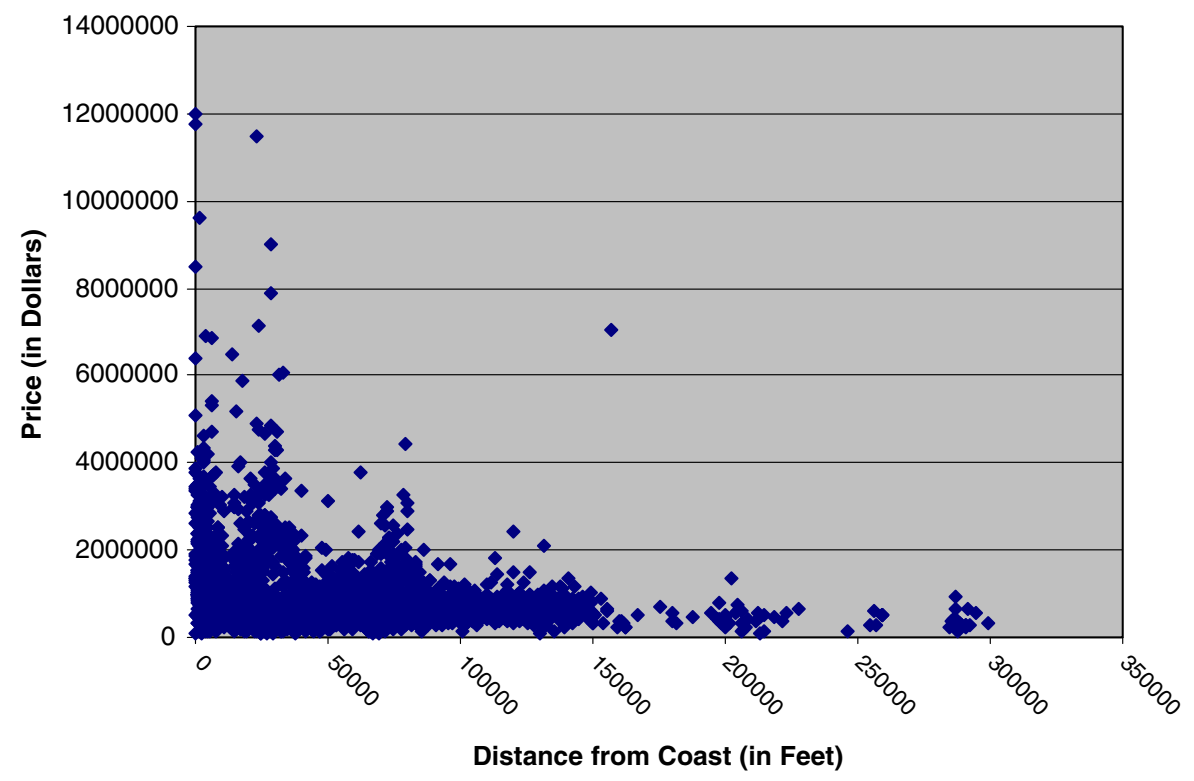

Fig. 2 House sale price as a function of distance from coast

We include fixed effects dummies for neighborhoods within the City of San Diego and ZIP codes for county subdivisions outside of the San Diego city limits (see Appendix, Table 3 for a detailed list) in order to control for possible sub-market housing effects within the greater County of San Diego. A potential problem with the structure of the data is the presence of "clusters" or groups. Although many characteristics of the house are captured in the model by various regressors, obviously not every aspect has been accounted for. For instance, there may be factors about the particular neighborhood in which a home is located that affect the pricing of the house and are unrelated to the other measures already in place in the model. Any of these aspects of the neighborhood that are not included in the model will then be included in the error term. The potential presence of these cluster effects may cause endogeneity in the error term, $\nu_{i}$. If, for instance, not only the nicer houses in a particular sub-region of the county (e.g., La Jolla) are priced higher, but also the higher prices of houses in La Jolla encourage construction companies to build nicer houses there, then the error term is not exogenously determined.

Wooldridge (2003) offers techniques to overcome the problems associated with the presence of clustering in the data depending on the form of the clusters. One possible structure of the group effects is to have a large number of clusters, $F$, (growing towards infinity) and relatively few observations within each group. Since it is believed that the group effects are correlated with the regressors the within-estimator or fixed effects should be used to consistently estimate the coefficients. Wooldridge suggests that the number of groups must be larger than 40-50 to be considered large. In this current endeavor, we have 106 neighborhoods, a relatively large number of clusters, thus the fixed effects method will be employed. Descriptive statistics, including the variables (and their description) by category are provided in Table 1. 
Table 1 Descriptive statistics of the variables

\begin{tabular}{|c|c|c|c|c|c|}
\hline Variable & Description & Mean & Std Dev & Min & Max \\
\hline \multicolumn{6}{|l|}{ Dependent variable } \\
\hline Ln_Price & $\begin{array}{l}\text { Natural logarithm of sales } \\
\text { price }\end{array}$ & 13.31098 & 0.454904 & 11.513 & 16.30 \\
\hline Price & Sales price of house & 691887.9 & 556376.9 & 100,000 & $12,000,000$ \\
\hline \multicolumn{6}{|c|}{ Structural characteristics } \\
\hline Age & Age of house (in years) & 37.45743 & 15.61142 & 1 & 98.00 \\
\hline Age_2 & Age of house squared & 1646.751 & 1249.535 & 1 & $9,604.00$ \\
\hline Bedrooms & Number of bedrooms & 3.306775 & 0.820486 & 1 & 8.00 \\
\hline Bathrooms & Number of bathrooms & 2.176845 & 0.825796 & 0.5 & 13.50 \\
\hline SqftStruc & Square footage of house & 1818.762 & 943.3803 & 336 & $16,281.00$ \\
\hline LotSqft & $\begin{array}{l}\text { Square footage of lot on } \\
\text { which house is situated }\end{array}$ & 22060.86 & 102943.1 & 1210 & $8,455,867$ \\
\hline \multicolumn{6}{|c|}{ Spatial and neighborhood variables } \\
\hline DtownDist & $\begin{array}{l}\text { Distance (in feet) from } \\
\text { house to downtown }\end{array}$ & 85888.85 & 55667.39 & 6906.7 & 306,053 \\
\hline LnDtownDist & $\begin{array}{l}\text { Natural logarithm of } \\
\text { Dtowndist }\end{array}$ & 11.14917 & 0.664710 & 8.84025 & 12.63151 \\
\hline FreeDist & $\begin{array}{l}\text { Distance (in feet) from } \\
\text { house to nearest freeway }\end{array}$ & 11116.37 & 12194.96 & 87.611 & 158,716 \\
\hline LnFreeDist & Natural logarithm of Freedist & 8.857125 & 1.026237 & 4.4729 & 11.97487 \\
\hline Dist_API & $\begin{array}{l}\text { Elementary school district's } \\
\text { base Academic Perform. } \\
\text { Index }(200-1,000)\end{array}$ & 767.8436 & 57.2554 & 653 & 939.00 \\
\hline \multicolumn{6}{|l|}{ Coastal variables } \\
\hline CoastDist & $\begin{array}{l}\text { Distance (in feet) from } \\
\text { house to coast }\end{array}$ & 47975.45 & 33182.93 & 73.747 & 299,490 \\
\hline LnCoastDist & $\begin{array}{l}\text { Natural logarithm of } \\
\text { Coastdist }\end{array}$ & 10.46281 & $9.65 \mathrm{E}-01$ & 4.3006 & $1.26 \mathrm{E}+01$ \\
\hline Coast_500ft & $\begin{array}{l}\text { Dummy: Res. within } \\
500 \mathrm{ft} \text {. of coast }\end{array}$ & 0.003337 & 0.057671 & 0 & 1.00 \\
\hline Coast_1000ft & $\begin{array}{l}\text { Dummy: Res. } 500 \text { to } \\
1,000 \mathrm{ft} \text {. of coast }\end{array}$ & 0.003842 & 0.061870 & 0 & 1.00 \\
\hline Coast_2000ft & $\begin{array}{l}\text { Dummy: Res. } 1,000 \text { to } \\
2,000 \mathrm{ft} \text {. of coast }\end{array}$ & 0.010111 & 0.10005 & 0 & 1.00 \\
\hline Coast_3000ft & $\begin{array}{l}\text { Dummy: Res. } 2,000 \text { to } \\
3,000 \mathrm{ft} \text {. of coast }\end{array}$ & 0.012437 & 0.110830 & 0 & 1.00 \\
\hline Coast_4000ft & $\begin{array}{l}\text { Dummy: Res. } 3,000 \text { to } \\
4,000 \mathrm{ft} \text {. of coast }\end{array}$ & 0.012134 & 0.109487 & 0 & 1.00 \\
\hline Coast_5280ft & $\begin{array}{l}\text { Dummy: Res. } 4,000 \text { to } \\
5,280 \mathrm{ft} \text {. of coast }\end{array}$ & 0.017189 & 0.129982 & 0 & 1.00 \\
\hline Coast_0to1miles & $\begin{array}{l}\text { Dummy: Res. within } 1 \text { mile } \\
\text { of coast }\end{array}$ & 0.059050 & 0.235729 & 0 & 1.00 \\
\hline Coast_2miles & $\begin{array}{l}\text { Dummy: Res. } 1 \text { to } 2 \text { miles } \\
\text { of coast }\end{array}$ & 0.047725 & 0.213195 & 0 & 1.00 \\
\hline Coast_3miles & $\begin{array}{l}\text { Dummy: Res. } 2 \text { to } 3 \text { miles } \\
\text { of coast }\end{array}$ & 0.044692 & 0.206636 & 0 & 1.00 \\
\hline
\end{tabular}


Table 1 (continued)

\begin{tabular}{llllll}
\hline Variable & Description & Mean & Std Dev & Min & Max \\
\hline Coast_4miles & $\begin{array}{c}\text { Dummy: Res. 3 to 4 miles } \\
\text { of coast }\end{array}$ & 0.052578 & 0.223202 & 0 & 1.00 \\
Coast_5miles & $\begin{array}{l}\text { Dummy: Res. } 4 \text { to 5 miles } \\
\text { of coast } \\
\text { Dummy: Res 5 to 6 miles } \\
\text { of coast }\end{array}$ & 0.062892 & 0.24278 & 0 & 1.00 \\
& & & 0.074722 & 0 & 1.00
\end{tabular}

Equation (2) provides an estimate for the (natural log) coastal premium, $\beta_{l}$. However, this is essentially an average premium measured at the mean for the entire data set. Since we expect the effect to be nonlinear, we construct a piece-wise linear spline of the distance from coast in order to estimate the effect of living within one mile of the coast, between one and two miles, etc. Thus, we adjust (2) to the following:

$$
\ln P_{i}=\alpha_{i}+\sum_{j=1}^{J} \beta_{j} S_{i j}+\sum_{k=1}^{K} \beta_{k} T_{i k}+\sum_{l=1}^{L} \beta_{l} D_{i l}+\sum_{m=1}^{M} \beta_{m} F_{i m}+v_{i},(\text { for } i=1,2, \ldots n)
$$

where $D_{i l}$ is a dummy variable denoting a specific distance from the coast for observation $i$. This corresponds to "Model 2" in our regression estimates. We can also adjust the distance dummy variables into smaller increments to capture even smaller distance effects, i.e., within 500 feet, between 500 and 1,000 feet, etc. (our "Model 3"). ${ }^{3}$

\section{Results}

We present the results of the standard hedonic pricing model in Table 2. Model 1 includes the log coastal distance variable which provides the coastal premium estimation. In this model, all coefficients are significant at the $1 \%$ level, except for LotSqft, which is still significant at the 5\% level and Bedrooms, which is not significant in any of the models. While the non-effect of having more bedrooms is somewhat surprising (e.g., in a meta analysis by Sirmans et al. 2006, the bedroom effect was positive and significant), there is some recent evidence for a similar, insignificant bedrooms effect in Boston (Stevenson 2004). Closer to home, the

\footnotetext{
3 These distance increments were somewhat arbitrarily selected, with the intention of capturing homes that are very close to the ocean-within 500 feet-and beyond. In California, ocean-front property owners' property line extends only to the mean high tide (California Civil Code, Section 1009) so some typical waterfront amenities found in other parts of the country such as boat docks, launches, etc. are not feasible or relevant to this study. In addition, coastal bluffs, prevalent in San Diego County, can render direct private access to the beach impossible in certain areas. There are often limited public access points along the bluffs through which all beachgoers may pass (see Locklin 1999).
} 
Table 2 Semi-log fixed effects ${ }^{\mathrm{d}}$ regression results

\begin{tabular}{|c|c|c|c|c|c|c|}
\hline \multirow[t]{2}{*}{ Variable } & \multicolumn{2}{|l|}{ Model 1} & \multicolumn{2}{|l|}{ Model 2} & \multicolumn{2}{|l|}{ Model 3} \\
\hline & $\begin{array}{l}\text { Estimated } \\
\text { Coefficient }\end{array}$ & $\begin{array}{l}t- \\
\text { Statistic }\end{array}$ & $\begin{array}{l}\text { Estimated } \\
\text { Coefficient }\end{array}$ & $\begin{array}{l}t- \\
\text { Statistic }\end{array}$ & $\begin{array}{l}\text { Estimated } \\
\text { Coefficient }\end{array}$ & $\begin{array}{l}t- \\
\text { Statistic }\end{array}$ \\
\hline \multicolumn{7}{|c|}{ Housing and school characteristics } \\
\hline Constant & $11.7966^{\mathrm{a}}$ & $(43.93)$ & $11.2239^{\mathrm{a}}$ & $(39.88)$ & $11.3138^{\mathrm{a}}$ & $(40.59)$ \\
\hline Age & $-0.007867^{\mathrm{a}}$ & $(-12.55)$ & $-0.007734^{\mathrm{a}}$ & $(-12.18)$ & $-0.007778^{\mathrm{a}}$ & $(-12.36)$ \\
\hline Age_2 & $0.000086^{\mathrm{a}}$ & $(11.63)$ & $0.000087^{\mathrm{a}}$ & $(11.65)$ & $0.000085^{\mathrm{a}}$ & $(11.41)$ \\
\hline Bedrooms & 0.002218 & $(0.63)$ & 0.002250 & $(0.64)$ & 0.003540 & $(1.01)$ \\
\hline Bathrooms & $0.042084^{\mathrm{a}}$ & $(8.05)$ & $0.045153^{\mathrm{a}}$ & $(8.55)$ & $0.041481^{\mathrm{a}}$ & $(7.92)$ \\
\hline SqftStruc & $0.000226^{\mathrm{a}}$ & $(47.76)$ & $0.000225^{\mathrm{a}}$ & $(46.92)$ & $0.000226^{\mathrm{a}}$ & $(47.68)$ \\
\hline LotSqft & $4.84 \mathrm{e}-08^{\mathrm{b}}$ & $(2.24)$ & $4.73 \mathrm{e}-08^{\mathrm{b}}$ & $(2.16)$ & $4.87 \mathrm{e}-08^{\mathrm{b}}$ & $(2.24)$ \\
\hline \multicolumn{7}{|c|}{ Spatial and neighborhood variables } \\
\hline LnDtownDist & $0.175223^{\mathrm{a}}$ & $(7.66)$ & $0.076875^{\mathrm{a}}$ & $(3.29)$ & $0.075096^{\mathrm{a}}$ & $(3.25)$ \\
\hline LnFreeDist & $0.010732^{\mathrm{a}}$ & $(3.06)$ & $0.015182^{\mathrm{a}}$ & $(4.17)$ & $0.009351^{\mathrm{a}}$ & $(2.57)$ \\
\hline Dist_API & $0.000956^{\mathrm{a}}$ & $(5.87)$ & $0.001068^{\mathrm{a}}$ & $(6.48)$ & $0.001046^{\mathrm{a}}$ & $(6.41)$ \\
\hline \multicolumn{7}{|l|}{ Coastal variables } \\
\hline LnCoastDist & $-0.146047^{\mathrm{a}}$ & $(-21.12)$ & & & & \\
\hline Coast_500ft & & & & & $0.702698^{\mathrm{a}}$ & $(15.43)$ \\
\hline Coast_1000ft & & & & & $0.487333^{\mathrm{a}}$ & $(11.11)$ \\
\hline Coast_2000ft & & & & & $0.454806^{\mathrm{a}}$ & $(13.67)$ \\
\hline Coast_3000ft & & & & & $0.438393^{\mathrm{a}}$ & $(13.97)$ \\
\hline Coast_4000ft & & & & & $0.293654^{\mathrm{a}}$ & $(9.38)$ \\
\hline Coast_5280ft & & & & & $0.201110^{\mathrm{a}}$ & $(6.77)$ \\
\hline Coast_0to1miles & & & $0.352211^{\mathrm{a}}$ & $(13.40)$ & & \\
\hline Coast_2miles & & & $0.200634^{\mathrm{a}}$ & $(7.92)$ & $0.193321^{\mathrm{a}}$ & $(7.71)$ \\
\hline Coast_3miles & & & $0.118684^{\mathrm{a}}$ & $(5.24)$ & $0.115352^{\mathrm{a}}$ & $(5.15)$ \\
\hline Coast_4miles & & & $0.082033^{\mathrm{a}}$ & $(4.13)$ & $0.082574^{\mathrm{a}}$ & $(4.20)$ \\
\hline Coast_5miles & & & $0.053282^{\mathrm{a}}$ & $(3.00)$ & $0.053941^{\mathrm{a}}$ & $(3.07)$ \\
\hline Coast_6miles & & & $0.035755^{\mathrm{a}}$ & $(2.59)$ & $0.033207^{\mathrm{b}}$ & $(2.43)$ \\
\hline \multicolumn{7}{|l|}{ Model statistics } \\
\hline Adj. R-Squared & 0.7798 & & 0.7749 & & 0.7795 & \\
\hline F-Statistic & 301.34 & & 280.79 & & 276.80 & \\
\hline Number of Obs. & 9755 & & 9755 & & 9755 & \\
\hline
\end{tabular}

\footnotetext{
a indicate significance at the 0.01 levels

$\mathrm{b}$ indicate significance at the 0.05 levels

${ }^{c}$ indicate significance at the 0.10 levels

${ }^{\mathrm{d}}$ Fixed effects parameter coefficients for each of 106 neighborhoods omitted here for brevity
}

bedroom effect for the Orange County study by Boarnet and Chalermpong (2001) was actually negative. Perhaps buyers in some markets prefer "space" to "bedrooms," especially as the large Baby Boom cohort enters its peak earnings years, leaving the childbearing years behind. Indeed, in a recent demographic report of San 
Diego County, the three cities with the lowest percentage of children (Solana Beach, Coronado and Del Mar) were among the top four in terms of median household income (SANDAG 2006).

The variable of interest, LnCoastDist is -0.146 , suggesting that a $10 \%$ increase in distance from the coast is associated with a $1.46 \%$ decline in price. ${ }^{4}$ To state this in a more concrete way, since the median house price for the sample is $\$ 540,000$ and the mean distance from the coast is $47,975.45$ feet (approximately 9.09 miles), then taking a median-priced house at the mean distance from the coast, a $10 \%$ increase in distance from the coast (or 4,797.5 feet) would correspond to a $\$ 7,886.20$ reduction in price. Extending this to get to a one-mile increment $(11 \%$ of the mean distance, corresponding to a $1.61 \%$ decreases in price), the effect of moving one mile away would be approximately $\$ 8,680$. While this is considerably lower than the finding for Orange County, there are several important considerations. First, the result from Boarnet and Chalermpong (2001) was actually for the San Joaquin Hills Transportation Corridor, which runs through the more affluent South Orange County region near Laguna Beach, Laguna Niguel and Aliso Viejo. Second, while actual mean coastal distance for this subsample was not presented in their paper, a casual inspection of the map provided suggests a much lower mean than this current investigation's 9.09 miles and their data appear to be in a fairly narrow band around the 73 freeway. At 299,416 feet (or about 56.7 miles), the span of this data set for San Diego County is certainly much larger than the entire width (east-west range) for all of Orange County.

Results presented for Model 1 also suggest that an additional bathroom is associated with a $4.3 \%$ higher sales price. ${ }^{5}$ Square feet of structure is the most significant coefficient and the estimated coefficient implies that a 100 square foot increase in structure is associated with a $2.29 \%$ higher price. Lot square footage is only significant at the 5\% level and the effect is much smaller, with each 1,000 additional square foot of lot size associated with about a $0.005 \%$ higher price. The coefficients for age and age-squared imply that price declines with age, though the effect becomes less as age increases. In other words, doubling the age would not double the negative "age effect." Perhaps the "new home" amenity (whether perceived or due to actual structural characteristics) depreciates rapidly and then any negative "age effects" quickly stabilize. The effect of higher Academic Performance Index (API) is also in the expected direction, with house price increasing by $10.03 \%$ for a 100-point increase in the local elementary school's mean API. While not reported in Table 2, fixed effects by neighborhood or ZIP code are presented in the Appendix, Table 3. University City, a somewhat upscale neighborhood northeast of downtown was omitted as the reference category. The largest fixed effect is for Coronado, certainly a well-known landmark and upscale neighborhood, whose coefficient of 0.795 translates to a $121.4 \%$ higher price.

\footnotetext{
${ }^{4}$ Following Ramanathan (1993) and others, we interpret log-log coefficients as elasticities.

${ }^{5}$ Following Thornton and Innes (1989) and Halvorsen and Palmquist (1980), interpretation of semilogarithmic regression coefficients follows: $\mathrm{g}=100 *[\exp (\mathrm{b} \Delta \mathrm{X})-1]$, where $\Delta X$ is $\mathrm{a}$ (noninfinitesimal) change in variable $\mathrm{X}, b$ is the regression coefficient and $g$ can be interpreted as the percent change in the dependent variable as a result of $\Delta X$.
} 
The results for distance from freeway and distance to downtown are somewhat puzzling, at least at first glance. The log distance from the freeway (LnFreeDist) variable is positive. While this is somewhat counter-intuitive (i.e., one may expect distance from the freeway to be associated with a lower sales price since it implies longer commute times), we believe that the fairly robust coverage of freeways throughout this region, particularly with I-5, I-15 and I-805 major freeways running north and south, along with additional support highways (163 and 125 among others) may mean that access to a freeway is not a serious issue in terms of commuting (and hence, housing location choice). On the contrary, given adequate freeway coverage in the region, the negative noise and air pollution effects associated with busy freeways (see Langley 1976) would provide a negative external effect on nearby residential properties. ${ }^{6}$

The log distance from downtown (LnDowntownDist) is also positive, suggesting that home prices increase with distance from downtown. Though this runs counter to the classic literature by Muth (1969) a more recent assessment by Giuliano (1989, 154) suggests that "available evidence shows that transport cost has decreased in importance as a locational consideration both for households and for firms. . . . Existing evidence suggests that neighborhood characteristics and access to activities other than work play an important role in location choice." She goes on to note that access to amenities and good schools are likely to be important drivers in household location decisions.

Results for Model 2 are quite similar, though we have included coastal distance dummies by mile up to six miles. ${ }^{7}$ As such, we estimate stratified coastal premiums based on distance from the coast. The effect is quite dramatic here, with houses located within one mile of the coastline being associated with a $42.2 \%$ increase in the estimated sales price, compared to all houses located beyond six miles of the coast (the reference category). This effect declines monotonically (with a generally similar trend in the significance levels) from $22.2 \%$ for houses between one and two miles to $12.6 \%$ for those between two and three miles, $8.5 \%$ for those between three and four miles, $5.5 \%$ for those between four and five miles until, for houses located between five and six miles of the coast, the coastal premium is only about $3.64 \%$. It is clear from this estimation that a simple approach to estimating the coastal premium (such as that offered in Model 1) may be not only oversimplified but actually misleading. For example, if the mean distance for the sample is 9.09 miles from the coast $(47,975.45$ feet), well beyond the 6-mile limit for a measurable coastal effect in this data set, then the effect on the coastal premium is actually likely to be zero at that point, not negative or positive. The strong negative coefficient in Model 1 is being driven by this negative effect but the gradient is apparently so large that the actual effect disappears before reaching the mean distance for the sample. These stratified coastal premiums are illustrated in Fig. 3 below.

In Model 3, we refine the coastal distance dummies to include roughly 1,000-feet increments for distances within one mile. Again, the effect is a monotonic decline in coastal premium, from a $101.9 \%$ premium for houses located within 500 feet of the coast, to $62.8 \%$ for those between 500 and 1,000 feet, to $57.6 \%$ for those between

\footnotetext{
${ }^{6}$ The SanGIS data are for the freeway, itself, not entry node.

${ }^{7}$ Additional estimations were performed for greater distances; however, the effects were not significant beyond six miles.
} 


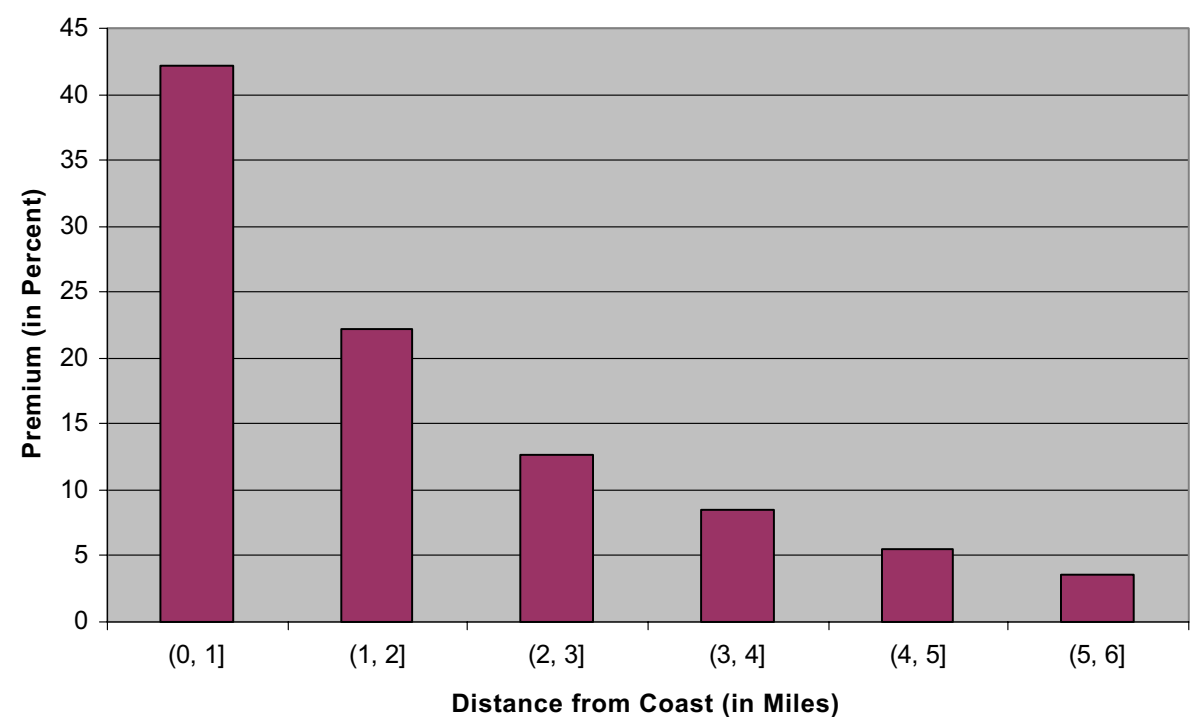

Fig. 3 Coastal premium (in Percent) for first six miles from coast

1,000 and 2,000 feet, all the way to $22.3 \%$ for those between 4,000 and 5,280 feet (see Fig. 4 for a summary of the stratified coastal premiums within one mile of the coast). The fixed "neighborhood effects" results discussed above for Model 1 are similar for Models 2 and 3. It is interesting to note that locations such as Coronado and La Jolla would receive both a fixed effect "neighborhood" premium (of, 86\%

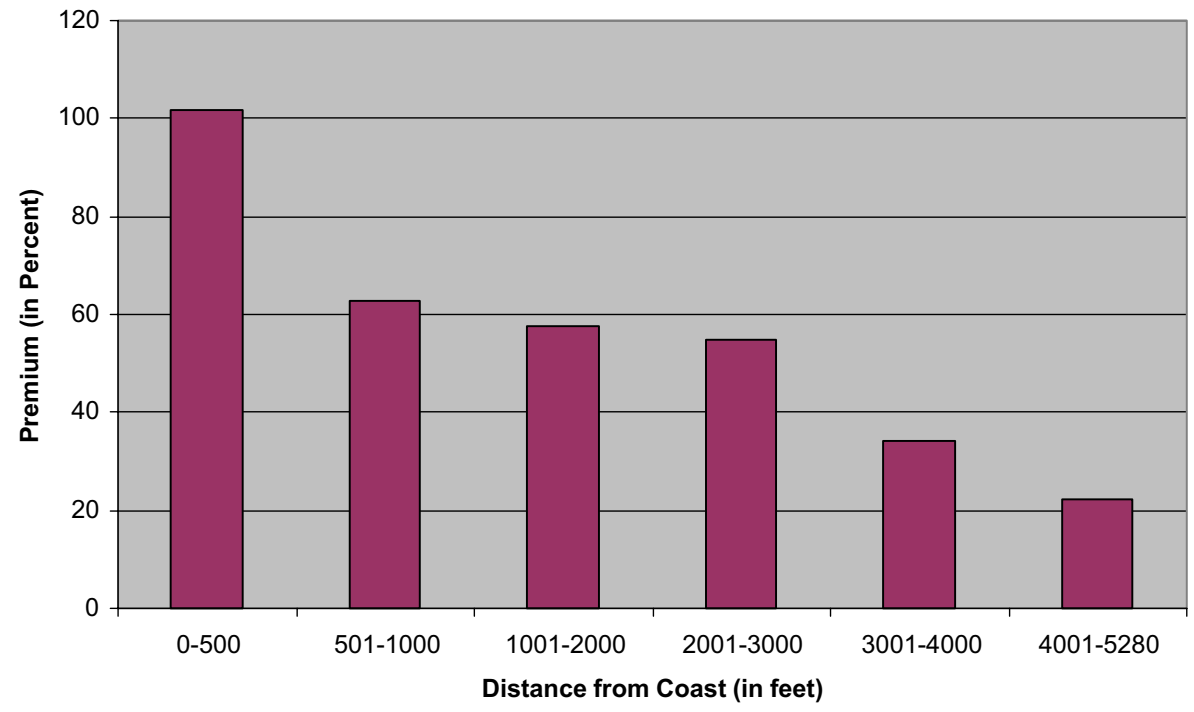

Fig. 4 Coastal premium (in Percent) for first one mile from coast 
and $65 \%$, respectively, using results from Model 3 in Appendix) and an additional coastal premium, since homes in these neighborhoods are located very near the coast. In sum, the coastal premium reported here is in addition to any other general "neighborhood amenities" premium. The adjusted R-square, at approximately 0.78 for all three models suggests that this model explains slightly more than threefourths of the variation in the (natural log of the) dependent variable.

\section{Conclusions}

In this analysis, we have attempted to estimate the effect on housing prices of locating near the coast. Results presented here are suggestive that proximity to the coast has a large and positive effect on the value of a house. In the basic semi-log hedonic regression model, we estimate that an additional mile from the coast for a house priced at the median and located at the mean distance from the coast is associated with an approximately $\$ 8,680$ decrease in value. While this is considerably lower than for a previously published report for Orange County, California of $\$ 42,000$ (Boarnet and Chalermpong 2001), several reasons were offered, particularly that the Orange County result was for a subset of data located in a fairly narrow band relatively close to the coast in affluent South Orange County.

We find very strong evidence that this effect is nonlinear in distance from the coast. While it may be quite large for homes very close to the coast-possibly increasing the value for homes within 500 feet of the coastline by an estimated $101.9 \%$ (compared to all homes beyond six miles of the coast), falling to $62.8 \%$ for homes between 500 and 1,000 feet of the coast, and so on-results presented here are suggestive that the effect declines rapidly (falling to about $21.3 \%$ for houses between one and two miles of the coast), and ultimately becoming negligible beyond six miles from the coast. Our model included fixed neighborhood effects in order to control for unobserved spatial heterogeneity not otherwise controlled for in the model. These fixed effects had expected relative magnitudes, with locations such as Coronado, La Playa, La Jolla, Mission Hills, Del Mar and Rancho Santa Fe all with positive coefficients and in the top 20 locations.

While these estimations had adjusted R-square values in line with other published research in this area (explaining around $78 \%$ of the variation in the dependent variable), we note that additional environmental variables such as crime rates and parks may improve upon the model specification. However, we do not believe that these would significantly alter the coastal premium estimates presented here.

In terms of limitations for this study, just as housing, in hedonic regressions, is assumed to be a composite good comprised of a variety of attributes, the premium itself, may be comprised of several amenities including access to the beach, cleaner air, views of the ocean, milder temperatures, etc. As such, what we have estimated as the "coastal premium" could actually be an amalgamation of some or all of these attributes. We leave this exercise for future research.

Acknowledgments We would like to thank Alan Gin, Andrew Narwold, Zhi-Yong "John" Yin, Elaine Worzalla, Jon Sandy, Dirk Yandell, the Burnham-Moores Center for Real Estate at the University of San Diego, two anonymous referees, and Le Anne Plaza for capable research assistance. Any errors belong solely to the authors. 
Open Access This article is distributed under the terms of the Creative Commons Attribution Noncommercial License which permits any noncommercial use, distribution, and reproduction in any medium, provided the original author(s) and source are credited.

\section{Appendix}

Table 3 Fixed effects coefficients for each area in sample

\begin{tabular}{|c|c|c|c|c|c|c|c|}
\hline \multirow{2}{*}{$\begin{array}{l}\text { Dummy } \\
\text { Variable } \\
\text { Number }\end{array}$} & \multirow{2}{*}{$\begin{array}{l}\text { Neighborhood/ } \\
\text { Area Name }\end{array}$} & \multicolumn{2}{|l|}{ Model 1} & \multicolumn{2}{|l|}{ Model 2} & \multicolumn{2}{|l|}{ Model 3} \\
\hline & & Coefficient & $t$-Statistic & Coefficient & $t$-Statistic & Coefficient & $t$-Statistic \\
\hline 1 & Adams North & 0.28927 & 4.59 & 0.18119 & 2.71 & 0.182391 & 2.76 \\
\hline 2 & Allied Gardens & 0.04901 & 1.53 & -0.05775 & -1.57 & -0.055051 & -1.52 \\
\hline 3 & Alta Vista & -0.09120 & -1.47 & -0.17225 & -2.66 & -0.167230 & -2.61 \\
\hline 4 & Bay Ho & -0.05230 & -1.65 & -0.07698 & -2.39 & -0.073174 & -2.29 \\
\hline 5 & Bay Park & 0.12506 & 3.91 & 0.07106 & 2.18 & 0.069225 & 2.15 \\
\hline 6 & Bay Terraces & -0.16586 & -5.46 & -0.23021 & -6.39 & -0.224297 & -6.29 \\
\hline 7 & Birdland & -0.01704 & -0.26 & -0.10723 & -1.61 & -0.106122 & -1.61 \\
\hline 8 & $\begin{array}{l}\text { Carmel } \\
\text { Mountain }\end{array}$ & -0.18879 & -4.52 & -0.22915 & -5.08 & -0.228515 & -5.12 \\
\hline 9 & Carmel Valley & -0.22690 & -5.11 & -0.19074 & -4.24 & -0.182397 & -4.1 \\
\hline 10 & Chollas Creek & -0.01958 & -0.30 & -0.12251 & -1.77 & -0.11643 & -1.7 \\
\hline 11 & $\begin{array}{l}\text { Clairemont } \\
\text { Mesa East }\end{array}$ & -0.04282 & -1.45 & -0.09474 & -2.86 & -0.094954 & -2.9 \\
\hline 12 & $\begin{array}{l}\text { Clairemont } \\
\text { Mesa West }\end{array}$ & -0.03336 & -1.03 & -0.08537 & -2.41 & -0.081550 & -2.32 \\
\hline 13 & College East & 0.04669 & 1.25 & -0.05524 & -1.32 & -0.054744 & -1.32 \\
\hline 14 & College West & 0.14982 & 4.20 & 0.04538 & 1.11 & 0.047855 & 1.19 \\
\hline 15 & Del Cerro & 0.20273 & 5.80 & 0.09975 & 2.52 & 0.097364 & 2.49 \\
\hline 16 & $\begin{array}{l}\text { Del Mar } \\
\text { Heights }\end{array}$ & 0.01915 & 0.37 & 0.04904 & 0.92 & 0.07717 & 1.46 \\
\hline 17 & $\begin{array}{l}\text { Egger } \\
\text { Highlands }\end{array}$ & -0.31759 & -8.28 & -0.31390 & -7.98 & -0.297656 & -7.64 \\
\hline 18 & El Cerrito & -0.02035 & -0.44 & -0.12419 & -2.45 & -0.116716 & -2.33 \\
\hline 19 & Emerald Hills & -0.05906 & -0.91 & -0.14561 & -2.12 & -0.139839 & -2.06 \\
\hline 20 & Encanto & -0.16363 & -4.70 & -0.24374 & -6.09 & -0.238071 & -6.01 \\
\hline 21 & Fairmont Park & 0.09880 & 1.82 & -0.03441 & -0.61 & -0.043679 & -0.78 \\
\hline 22 & $\begin{array}{c}\text { Jamacha } \\
\text { Lomita }\end{array}$ & -0.11405 & -3.26 & -0.19814 & -4.97 & -0.188044 & -4.77 \\
\hline 23 & Kensington & 0.49584 & 11.61 & 0.38714 & 8.16 & 0.390514 & 8.32 \\
\hline 24 & La Jolla & 0.48319 & 17.16 & 0.53742 & 18.10 & 0.500030 & 16.89 \\
\hline 25 & La Playa & 0.59002 & 11.97 & 0.49965 & 9.60 & 0.566019 & 10.94 \\
\hline 26 & Lake Murray & -0.01612 & -0.51 & -0.12774 & -3.56 & -0.122028 & -3.44 \\
\hline 27 & Lincoln Park & -0.23100 & -3.42 & -0.32725 & -4.69 & -0.329624 & -4.78 \\
\hline 28 & Linda Vista & 0.03438 & 0.79 & -0.05841 & -1.27 & -0.053966 & -1.18 \\
\hline 29 & Loma Portal & 0.26730 & 5.87 & 0.16731 & 3.56 & 0.180524 & 3.88 \\
\hline 30 & Midtown & 0.49938 & 7.10 & 0.34434 & 4.79 & 0.346354 & 4.87 \\
\hline
\end{tabular}


Table 3 (continued)

\begin{tabular}{|c|c|c|c|c|c|c|c|}
\hline \multirow{2}{*}{$\begin{array}{l}\text { Dummy } \\
\text { Variable } \\
\text { Number }\end{array}$} & \multirow{2}{*}{$\begin{array}{l}\text { Neighborhood/ } \\
\text { Area Name }\end{array}$} & \multicolumn{2}{|l|}{ Model 1} & \multicolumn{2}{|l|}{ Model 2} & \multicolumn{2}{|l|}{ Model 3} \\
\hline & & Coefficient & $t$-Statistic & Coefficient & $t$-Statistic & Coefficient & $t$-Statistic \\
\hline 31 & Mira Mesa & -0.17876 & -6.91 & -0.17060 & -5.61 & -0.166830 & -5.54 \\
\hline 32 & $\begin{array}{l}\text { Miramar Ranch } \\
\text { North }\end{array}$ & -0.06266 & -1.25 & -0.08657 & -1.63 & -0.087594 & -1.67 \\
\hline 33 & Mission Hills & 0.60679 & 12.50 & 0.46618 & 9.40 & 0.468856 & 9.55 \\
\hline 34 & Mountain View & -0.11201 & -2.06 & -0.21336 & -3.75 & -0.217225 & -3.85 \\
\hline 35 & Nestor & -0.30624 & -8.24 & -0.28427 & -7.53 & -0.290085 & -7.76 \\
\hline 36 & $\begin{array}{l}\text { North } \\
\text { Clairmont }\end{array}$ & -0.06973 & -2.28 & -0.09314 & -2.92 & -0.090670 & -2.87 \\
\hline 37 & North Park & 0.37026 & 6.10 & 0.20721 & 3.31 & 0.2102822 & 3.39 \\
\hline 38 & Oak Park & -0.02968 & -0.81 & -0.12551 & -2.99 & -0.119818 & -2.88 \\
\hline 39 & $\begin{array}{l}\text { Otay Mesa } \\
\text { West }\end{array}$ & -0.25950 & -8.65 & -0.26194 & -8.10 & -0.263984 & -8.25 \\
\hline 40 & Pacific Beach & 0.19852 & 6.42 & 0.17414 & 5.31 & 0.1955586 & 6.01 \\
\hline 41 & Paradise Hills & -0.07725 & -2.21 & -0.14286 & -3.68 & -0.136876 & -3.56 \\
\hline 42 & $\begin{array}{l}\text { Point Loma } \\
\text { Heights }\end{array}$ & 0.10439 & 2.89 & 0.01869 & 0.48 & 0.061810 & 1.59 \\
\hline 43 & $\begin{array}{l}\text { Rancho } \\
\text { Bernardo }\end{array}$ & -0.25249 & -6.95 & -0.29109 & -7.32 & -0.288715 & -7.33 \\
\hline 44 & $\begin{array}{l}\text { Rancho } \\
\text { Penasquitos }\end{array}$ & -0.24791 & -7.21 & -0.25299 & -6.56 & -0.248629 & -6.52 \\
\hline 45 & $\begin{array}{l}\text { Redwood } \\
\text { Village/ } \\
\text { Rolando Park }\end{array}$ & -0.04673 & -1.30 & -0.14748 & -3.61 & -0.139700 & -3.46 \\
\hline 46 & $\begin{array}{l}\text { Ridgeview/ } \\
\text { Webster }\end{array}$ & -0.01280 & -0.25 & -0.12444 & -2.32 & -0.123291 & -2.32 \\
\hline 47 & Rolando & 0.02701 & 0.67 & -0.07682 & -1.72 & -0.070189 & -1.58 \\
\hline 48 & $\begin{array}{l}\text { Roseville/Fleet } \\
\text { Ridge }\end{array}$ & 0.32390 & 6.53 & 0.24412 & 4.68 & 0.285232 & 5.51 \\
\hline 49 & Sabre Springs & -0.17211 & -3.28 & -0.21201 & -3.82 & -0.211167 & -3.85 \\
\hline 50 & San Carlos & 0.07392 & 2.21 & -0.03514 & -0.93 & -0.030838 & -0.83 \\
\hline 51 & San Ysidro & -0.23873 & -5.05 & -0.21912 & -4.49 & -0.227604 & -4.71 \\
\hline 52 & Scripps Ranch & -0.02174 & -0.72 & -0.06663 & -1.95 & -0.062204 & -1.84 \\
\hline 53 & Serra Mesa & 0.01262 & 0.38 & -0.06808 & -1.77 & -0.067867 & -1.78 \\
\hline 54 & Skyline & -0.15035 & -4.18 & -0.22852 & -5.59 & -0.220226 & -5.44 \\
\hline 55 & Sunset Cliffs & 0.15960 & 3.31 & 0.18815 & 3.75 & 0.102672 & 2.04 \\
\hline 56 & Talmadge & 0.25699 & 6.08 & 0.14829 & 3.15 & 0.155251 & 3.33 \\
\hline 57 & Tierrasanta & 0.07548 & 2.52 & -0.01000 & -0.29 & -0.008803 & -0.25 \\
\hline 58 & University City & Reference & Reference & Reference & Reference & Reference & Reference \\
\hline 59 & $\begin{array}{l}\text { University } \\
\text { Heights }\end{array}$ & 0.30387 & 4.00 & 0.16772 & 2.15 & 0.1699697 & 2.2 \\
\hline 60 & Valencia Park & -0.14738 & -3.46 & -0.24302 & -5.31 & -0.239873 & -5.29 \\
\hline 61 & Wooded Area & 0.32130 & 5.94 & 0.25579 & 4.49 & 0.237969 & 4.19 \\
\hline 62 & Alpine & -0.06862 & -1.70 & -0.20178 & -4.77 & -0.200639 & -4.79 \\
\hline
\end{tabular}


Table 3 (continued)

\begin{tabular}{|c|c|c|c|c|c|c|c|}
\hline \multirow{2}{*}{$\begin{array}{l}\text { Dummy } \\
\text { Variable } \\
\text { Number }\end{array}$} & \multirow{2}{*}{$\begin{array}{l}\text { Neighborhood/ } \\
\text { Area Name }\end{array}$} & \multicolumn{2}{|l|}{ Model 1} & \multicolumn{2}{|l|}{ Model 2} & \multicolumn{2}{|l|}{ Model 3} \\
\hline & & Coefficient & $t$-Statistic & Coefficient & $t$-Statistic & Coefficient & $t$-Statistic \\
\hline 63 & Bonita & 0.09817 & 2.25 & 0.03829 & 0.81 & 0.0445891 & 0.95 \\
\hline 64 & Chula Vista & -0.12586 & -4.38 & -0.16545 & -5.37 & -0.163104 & -5.35 \\
\hline 65 & Chula Vista & -0.14830 & -5.38 & -0.17702 & -5.68 & -0.177358 & -5.75 \\
\hline 66 & Chula Vista & -0.04784 & -0.92 & -0.10239 & -1.85 & -0.094617 & -1.72 \\
\hline 67 & Imperial Beach & -0.35680 & -10.07 & -0.36678 & -9.76 & -0.327387 & -8.77 \\
\hline 68 & Jamul & 0.00308 & 0.07 & -0.10917 & -2.42 & -0.097273 & -2.18 \\
\hline 69 & La Mesa & -0.01517 & -0.53 & -0.12031 & -3.57 & -0.114246 & -3.43 \\
\hline 70 & La Mesa & -0.01353 & -0.43 & -0.12279 & -3.44 & -0.120666 & -3.42 \\
\hline 71 & Lemon Grove & -0.08566 & -2.73 & -0.17847 & -4.90 & -0.168174 & -4.66 \\
\hline 72 & National City & -0.06829 & -1.87 & -0.15213 & -3.93 & -0.150348 & -3.93 \\
\hline 73 & Spring Valley & -0.13428 & -4.66 & -0.22682 & -6.69 & -0.216723 & -6.46 \\
\hline 74 & Spring Valley & -0.14937 & -3.56 & -0.25453 & -5.62 & -0.243374 & -5.43 \\
\hline 75 & Bonsall & -0.20346 & -3.51 & -0.17813 & -2.96 & -0.168412 & -2.83 \\
\hline 76 & $\begin{array}{l}\text { Borrego } \\
\text { Springs }\end{array}$ & -0.48494 & -7.28 & -0.63586 & -9.43 & -0.616979 & -9.24 \\
\hline 77 & $\begin{array}{c}\text { Cardiff-By- } \\
\text { The-Sea }\end{array}$ & -0.37486 & -7.28 & -0.30723 & -5.86 & -0.256439 & -4.92 \\
\hline 78 & Carlsbad & -0.42648 & -9.68 & -0.31961 & -7.11 & -0.300920 & -6.75 \\
\hline 79 & Carlsbad & -0.20215 & -3.68 & -0.13294 & -2.34 & -0.122106 & -2.17 \\
\hline 80 & Del Mar & 0.14282 & 2.40 & 0.20353 & 3.36 & 0.176549 & 2.93 \\
\hline 81 & El Cajon & -0.06339 & -2.01 & -0.17889 & -5.16 & -0.174909 & -5.1 \\
\hline 82 & El Cajon & -0.06980 & -2.39 & -0.18120 & -5.46 & -0.178580 & -5.44 \\
\hline 83 & El Cajon & -0.09807 & -2.94 & -0.21435 & -5.90 & -0.213630 & -5.94 \\
\hline 84 & Encinitas & -0.25771 & -6.07 & -0.19005 & -4.43 & -0.181308 & -4.26 \\
\hline 85 & Escondido & -0.15033 & -4.10 & -0.17411 & -4.43 & -0.170918 & -4.39 \\
\hline 86 & Escondido & -0.24079 & -6.39 & -0.24816 & -6.15 & -0.245108 & -6.14 \\
\hline 87 & Escondido & -0.21075 & -5.89 & -0.24460 & -6.38 & -0.235583 & -6.21 \\
\hline 88 & Fallbrook & -0.23597 & -5.56 & -0.22067 & -4.94 & -0.210999 & -4.77 \\
\hline 89 & Escondido & -0.06510 & -1.66 & -0.06864 & -1.64 & -0.067351 & -1.62 \\
\hline 90 & Julian & -0.53007 & -8.98 & -0.69398 & -11.55 & -0.674622 & -11.34 \\
\hline 91 & Lakeside & -0.11258 & -3.26 & -0.23749 & -6.37 & -0.227898 & -6.18 \\
\hline 92 & Oceanside & -0.51933 & -12.71 & -0.39524 & -9.64 & -0.383747 & -9.44 \\
\hline 93 & Oceanside & -0.46783 & -11.42 & -0.36782 & -8.54 & -0.356750 & -8.37 \\
\hline 94 & Oceanside & -0.46307 & -10.62 & -0.36157 & -7.84 & -0.347510 & -7.61 \\
\hline 95 & Poway & -0.09670 & -2.67 & -0.16638 & -4.21 & -0.155905 & -3.98 \\
\hline 96 & Ramona & -0.18611 & -5.04 & -0.30823 & -7.91 & -0.292458 & -7.57 \\
\hline 97 & $\begin{array}{l}\text { Rancho Santa } \\
\text { Fe }\end{array}$ & 0.13079 & 2.77 & 0.16003 & 3.25 & 0.175013 & 3.59 \\
\hline 98 & San Marcos & -0.29376 & -7.32 & -0.27956 & -6.51 & -0.273430 & -6.43 \\
\hline 99 & Santee & -0.20511 & -6.09 & -0.32879 & -8.86 & -0.316647 & -8.62 \\
\hline 100 & Solana Beach & 0.04162 & 0.79 & 0.15963 & 3.01 & 0.090114 & 1.71 \\
\hline
\end{tabular}


Table 3 (continued)

\begin{tabular}{|c|c|c|c|c|c|c|c|}
\hline \multirow{2}{*}{$\begin{array}{l}\text { Dummy } \\
\text { Variable } \\
\text { Number }\end{array}$} & \multirow{2}{*}{$\begin{array}{l}\text { Neighborhood/ } \\
\text { Area Name }\end{array}$} & \multicolumn{2}{|l|}{ Model 1} & \multicolumn{2}{|l|}{ Model 2} & \multicolumn{2}{|l|}{ Model 3} \\
\hline & & Coefficient & $t$-Statistic & Coefficient & $t$-Statistic & Coefficient & $t$-Statistic \\
\hline 101 & San Marcos & -0.27519 & -6.36 & -0.21263 & -4.62 & -0.199022 & -4.36 \\
\hline 102 & Vista & -0.26917 & -5.18 & -0.19086 & -3.53 & -0.176459 & -3.29 \\
\hline 103 & Valley Center & -0.20051 & -4.54 & -0.25197 & -5.46 & -0.239539 & -5.24 \\
\hline 104 & Vista & -0.34522 & -8.21 & -0.25938 & -5.81 & -0.243949 & -5.52 \\
\hline 105 & Vista & -0.26089 & -6.78 & -0.19973 & -4.84 & -0.187505 & -4.59 \\
\hline 106 & Coronado & 0.79548 & 10.35 & 0.60568 & 7.55 & 0.6212371 & 7.76 \\
\hline
\end{tabular}

\section{References}

Benson, E. D., Hansen, J. L., Schwartz, A. L., Jr., \& Smersh, G. T. (1998). Pricing residential amenities: the value of a view. Journal of Real Estate Finance and Economics, 16(1), 55-73.

Blackley, P., Follain, J. R., Jr., \& Ondrich, J. (1984). Box-cox estimation of hedonic models: how serious is the iterative OLS variance bias? Review of Economics and Statistics, 66(2), 348-353.

Boarnet, M. G., \& Chalermpong, S. (2001). New highways, house prices, and urban development: a case study of toll roads in Orange County, CA. Housing Policy Debate, 12(3), 575-605.

Brasington, D. M. (1999). Which measures of school quality does the housing market value? Journal of Real Estate Research, 18(3), 395-413.

Cropper, M. L., Deck, L. B., \& McConnell, K. E. (1988). On the choice of functional form for hedonic price functions. Review of Economics and Statistics, 70(4), 668-675.

Freeman, A. M., III. (2003). The measurement of environmental and resource values: theory and methods (2nd ed.). Washington, D.C.: Resources for the Future.

Giuliano, G. (1989). New directions for understanding transportation and land use. Environment and Planning, 21, 145-159.

Halvorsen, R., \& Palmquist, R. (1980). The interpretation of dummy variables in semilogarithmic equations. American Economic Review, 70, 474-475.

Irwin, E. G. (2002). The effects of open space on residential property values. Land Economics, 78(4), $465-480$.

Kilpatrick, J. A., Throupe, R. L., Carruthers, J. I., \& Krause, A. (2007). The impact of transit corridors on residential property values. Journal of Real Estate Research, 29(3), 303-320.

Langley, J. C. (1976). Adverse impacts of the Washington beltway on residential property values. Land Economics, 52(1), 54-65.

Locklin, L. (1999). Public Access Action Plan. California Coastal Commission. World Wide Web page $<$ www.coastal.ca.gov/access/accesspl.pdf> (accessed May 11, 2009).

Mahan, B. L., Polasky, S., \& Adams, R. M. (2000). Valuing urban Wetlands: a property price approach. Land Economics, 76(1), 100-113.

Major, C., \& Lusht, K. M. (2004). Beach proximity and the distribution of property values in shore communities. The Appraisal Journal, 72, 333-338.

Muth, R. (1969). Cities and housing. Chicago, IL: University of Chicago Press.

Obenski, S., Farber, J., \& Chappell, G. (2006). Research to improve census imputation methods: Item results and conclusions. Working Paper: U.S. Census Bureau. World Wide Web page <http://www. census.gov/cac/www/pdf/imputation-methods.pdf $>$ (accessed on March 17, 2009).

Plattner, R. H., \& Campbell, T. J. (1978). A study of the effect of water view on site value. The Appraisal Journal, 78, 20-25.

Ramanathan, R. (1993). Statistical methods in econometrics. San Diego: Academic.

Ridker, R. G. (1967). Economic costs of air pollution: Studies in measurement. New York: Praeger.

Ridker, R. G., \& Henning, J. A. (1967). The determinants of residential property values with special reference to air pollution. Review of Economics and Statistics, 49(2), 246-257. 
Rinehart, J. R., \& Pompe, J. J. (1994). Adjusting the market value of coastal property for beach quality. The Appraisal Journal, LXII, 604-608.

Rodriguez, M., \& Sirmans, C. F. (1994). Quantifying the value of a view in single-family housing markets. The Appraisal Journal, 62, 600-603.

Rosen, S. (1974). Hedonic prices and implicit markets: product differentiation in pure competition. Journal of Political Economy, 82(1), 34-55.

SANDAG. (2006). San Diego region demographic and economic characteristics. (Monograph) San Diego: San Diego Association of Governments. June (1). World Wide Web page <http://www.sandag. org/uploads/publicationid/publicationid 1232 5564.pdf $>$ (accessed on June 20, 2007).

Sirmans, G. S., MacDonald, L., Macpherson, D. A., \& Zietz, E. N. (2006). The value of housing characteristics: a meta analysis. Journal of Real Estate Finance and Economics, 33, 215-240.

Stevenson, S. (2004). New empirical evidence on heteroskedasticity in hedonic housing models. Journal of Housing Economics, 13, 136-153.

Taylor, L. O., \& Smith, V. K. (2000). Environmental amenities as a source of market power. Land Economics, 76(4), 550-568.

Thornton, R. J., \& Innes, J. T. (1989). Interpreting semilogarithmic regression coefficients in labor research. Journal of Labor Research, X(4), 443-447.

Tiebout, C. M. (1956). A pure theory of local expenditures. Journal of Political Economy, 64(5), 416-424.

Tyravainen, L., \& Miettinen, A. (2000). Property prices and urban forest amenities. Journal of Environmental Economics and Management, 39(2), 205-223.

Wooldridge, J. (2003). Cluster-sample methods in applied econometrics. American Economic Review, 93 (2), 133-138.

Zajac, K. J. (2003). Analysis of imputation rates for the 100 percent person and housing unit data items from census 2000. (Monograph), U.S. Department of Commerce, Bureau of the Census. September 25. 103 pp. World Wide Web page <http://www.census.gov/pred/www/rpts/B.1.a.PDF> (accessed on June 18, 2007). 